\title{
Cellular Retinoic Acid-Binding Protein 2
}

National Cancer Institute

\section{Source}

National Cancer Institute. Cellular Retinoic Acid-Binding Protein 2. NCI Thesaurus. Code C104927.

Cellular retinoic acid-binding protein $2(138 \mathrm{aa}, \sim 16 \mathrm{kDa})$ is encoded by the human CRABP2 gene. This protein plays a role in retinoic acid signaling. 